\title{
Testing the Excess Return Hypothesis: The Canadian Case
}

Trevor W. Chamberlain and Abdul-Rahman Khokhar

A web appendix for this paper is available at:

http://dx.doi.org/10.15239/j.brcacadjb.2016.06.01.wa06

Trevor W. Chamberlain

DeGroote School of Business, McMaster University

1280 Main Street

West Hamilton, ON, L8S 4M4.

Tel: (905) 525-9140, x23980. Fax: (905) 521-8995.

Email: chambert@mcmaster.ca

Abdul-Rahman Khokhar

Sobey School of Business

St. Mary's University

923 Robie Street

Halifax, NS, B3H 3C3

Tel: (962) 491-6371. Fax: (902) 496-8101.

Email: Rahman.Khokhar@smu.ca

\begin{abstract}
This study examines the relationship between stock returns and the term structure of interest rates in a Canadian setting. Following
\end{abstract}


Zhou's study of the US market (Federal Reserve Board, 1996), the hypothesis tested is the excess return hypothesis, which states that expected returns move one-for-one with interest rates. This relationship is explored using nominal and real return data for Canadian stocks and bonds. In addition, given the close relationship between the Canadian and US economies, the study examines the ability of US interest rates to predict Canadian stock returns.

Using first differenced returns, the study finds that nominal Canadian interest rates have predictive power vis-à-vis nominal Canadian stock returns, but, unlike Zhou's (1996) results for the US, the relationship is negative. This is also true when real returns are used. As for US interest rates and Canadian stock returns, the relationship is of mixed sign and mainly insignificant for both nominal and real stock returns and interest rates. The only evidence supporting the excess return hypothesis occurs when two-stage least squares, using the short-term interest rate as an instrumental variable, are used to regress real Canadian stock returns on real US interest rates. Finally, tests to determine whether the results are dependent on the period studied indicate that they are not sample-dependent.

\section{JEL Classification: G10}

Keywords: Stock Returns, Interest Rates

Acknowledgements: The authors wish to thank session participants at the $9^{\text {th }}$ Annual Conference of Business Research Consortium of Western New York held in Rochester, NY and the $77^{\text {th }}$ IAES Conference held in Madrid for their helpful comments.

\section{InTRODUCTION AND Literature Review}

The relationship between stock prices and the term structure of interest rates has been examined in numerous studies utilizing US data. In an early study, Shiller (1981) explained the notion of efficient markets by attributing the volatility in stock prices to real interest rate changes. Subsequently, several attempts were made to predict stock returns using 
changes in the term structure. Flannery and James (1984) studied the effect of interest rate changes on the common stock returns of financial institutions. They used weekly stock return data for sixty-seven US commercial banks over the period January 1976 to November 1981 to find a correlation between common stock returns and interest rate changes. Likewise, Campbell (1987) used monthly US data between 1959 and 1983 to find that the term structure of interest rates predicts excess returns on stocks, bills and bonds. The study further examined simple asset pricing models and provided evidence that conditional variances of excess return change through time. Campbell also found a positive relationship between the conditional mean and the conditional variance at the short end of the term structure. Breen et al (1989) studied the economic significance of predictable variations in stock index returns and concluded that knowledge of the one-month interest rate is useful in forecasting the sign and variance of the excess return on stocks. This study documented a negative relationship between a stock index return and treasury bill interest rates using a value-weighted index. However, this relationship was not statistically or economically significant when an equally-weighted index was used. Ferson (1989) argued that the regression of security returns on treasury bill rates provides insights about the behaviour of risk in rational asset pricing models; that is, the changes in conditional betas, a measure of risk, are associated with interest rates.

A study by Jagadeesh (1990) rejected the hypothesis that stock prices follow a random walk and attributed predictability of stock returns either to market inefficiency or to systematic changes in expected stock returns. Campbell and Ammer (1993) used monthly postwar US data and a vector autoregression model to decompose excess stock returns and 10 -year bond returns into changes in the expectation of future stock dividends, inflation, short-term real interest rates, and excess stock and bond returns. The study found that stock returns are driven by news about future excess stock returns, whereas real interest rates had little effect. In addition, real interest rates were found to affect short-term nominal interest rates and the slope of the term structure. Zhou (1996) 


\section{The BRC Academy Journal of Business Vol. 6, No. 1}

used the term structure of interest rates to study the variation of stock prices and stock returns and found that interest rates had an important effect on long-horizon stock returns, especially for time horizons of twenty-four months or more. The paper supported the hypothesis that expected stock returns move one-for-one with ex-ante interest rates using real returns and long-horizon nominal returns.

In a more recent study, Domian and Reichenstein (2009) updated previous work and presented new evidence on the predictability of stock market returns. The study confirmed that stock returns are partially predictable while rejecting the random walk model. In another study, Czaja and Scholz (2009) examined the sensitivity of German stock returns to interest rate changes and concluded that the industry curvature and, to a lesser extent, the slope of the term structure, are useful in predicting variations in stock returns. The study also found that interest rate risk was of greater relevance for financial institutions than non-financial institutions.

One might expect to obtain results for Canada similar to those for the US, given the two countries geographic proximity and close economic relationship. Perhaps for these reasons, the relationship between Canadian stock returns and the term structure of interest rates does not appear to have been examined, with the exception of those studies which have examined momentum in Canadian stock returns. Cleary and Inglis (1998) argued that US and Canadian stock returns are predictable for short term horizons, and "abnormal profits have been generated by purchasing previous strong performers and selling previous poor performers" (p. 279). Similarly, Deaves and Miu (2007) concluded that "cross-section returns are predictable using both momentum and reversal strategies for Canadian financial markets," while testing "whether momentum profit in Canada could be improved on by conditioning on the term structure of prior returns" (p. 135).

The above notwithstanding, whether there is a relationship between Canadian stock returns and the term structure deserves to be empirically 
tested. This is the objective of the current study. Using an approach similar to that of Zhou (1996) we test the hypothesis that expected stock returns move one-for-one with ex-ante interest rates, which is also known as the excess return hypothesis. The relationship is explored using nominal and real data for stocks and the Canadian term structure. In addition, the paper examines the ability of the US term structure to predict changes in Canadian stock returns. Inasmuch as American monetary policy has been found to have a major influence on Canadian monetary policy and interest rates (Khoury and Melard, 1985), and conventional wisdom holds that Canadian stock prices are affected by US interest rate changes (see for example, Tilak, 2015), we would expect to obtain results similar to those of Zhou (1998).

The study contributes to the existing literature inasmuch as it appears to be the first attempt to test empirically the excess return hypothesis using Canadian data. The paper also appears to be the first attempt to explore the possibility of a relationship between the US term structure and Canadian stock returns.

\section{Methodology}

\section{Data and Variables}

Toronto Stock Exchange (TSX) data are sourced from the Canadian Financial Markets Research Centre (CFMRC) Summary Information Database. The S\&P/TSX Monthly Price Index of stocks traded on the TSX is used to compute stock returns. Consistent with most empirical work in this area, $\log$ stock returns are calculated using equation 1 in Appendix 1, where variables are as defined in Exhibit 1 . The S\&P/TSX monthly price index data cover the period 1956:01 to 2008:06. Short and long horizon stock returns are estimated for six different periods, with n set equal to 3 , 12, 24, 36, 60 and 84 months. These periodic returns are then transformed into annualized stock returns using equation 2 in Appendix 1. 
The zero coupon bond yield for the matching maturity implied by the term structure (yield curve) for Canadian treasury securities is used as a proxy for the Canadian interest rate. Yield curve data are sourced from the Bank of Canada using 3, 12, 24, 36, 60 and 84 month maturity zero coupon Canadian treasury securities. The Canadian term structure data are only available since 1986:01, with the exception of the 3-month maturity zero coupon bond yield. The additional data for the 3-month maturity zero-coupon bond yield for the period 1956:01 to 1985:12 are sourced from the Canadian Socio-Economic Information Management System (CAMSIM) database.

To study the relationship between the US term structure and changes in Canadian stock returns, term structure data for US Treasury securities were also required. These data were sourced from two sources. Data for the period 1956:01 to 1991:02 were obtained from McCulloch and Kwon's (1993) dataset of zero-coupon bond yields implied by the yield curve of US treasury securities. Data for the period 1991:03 to 2009:01 were obtained from the Center for Research in Security Prices (CRSP) database through Wharton Research Data Services (WRDS).

To obtain real returns, the nominal data for each period were adjusted for, respectively, periodic US and Canadian inflation. Log inflation was computed using monthly Consumer Price Index (CPI) data and then annualized inflation for each month was computed using equation 3 in Appendix 1. Both Canadian and US CPI data were sourced through the CANSIM database for the period 1950:12 to 2008:06. Real stock returns and real interest rates were computed using equations 4 and 5 in Appendix 1.

Although the data for the S\&P/TSX Monthly Price Index of stocks began on 1956:01, the return data series start later depending on the value of n. For example, for the 84 month return period, the first monthly observation starts on 1963:01. The summary of observations for each variable is shown in Table 1.

Since the number of available observations for the Canadian term structure is limited to 270 , except for the 3-month rate for which 627 
observations are available, the overall analysis uses 270 observations for all variables starting from 1986:01. However, an additional analysis is conducted for the short-horizon (3-month) using all 627 observations for the period 1956:04 to 2008:06, and these results are then compared with the short-horizon (3-months) results obtained using 270 observations in an effort to identify any effects arising as a result of differences in sample size. This is discussed in the next section.

Sample means and standard deviations for asset returns and inflation for all six maturities are provided in Table 2. Sample means and standard deviations for the larger sample using 627 observations, and for the small sample, using 270 observations, are compared in Table 3.

Overall, from Table 3, we see that the larger sample tends to have a higher standard deviation, not only for nominal stock returns and nominal interest rates, but also for real stock returns and real interest rates. This is true for both the Canadian and US samples.

\section{Empirical Models}

The methodology to analyze the co-movements of stocks and bonds is similar to that used in Zhou (1996). The paper investigates the predictive power of bond yields for stock returns and tests the hypothesis that expected stock returns move one-for-one with ex-ante interest rates - the so-called excess return hypothesis. The model in equation 6 (Appendix 1) is used to test the hypothesis.

The objective of the analysis is to determine for what value of $n$, if any, the excess return hypothesis holds. In other words, a value, $b_{1}$, equal or close to 1 will support the hypothesis that expected stock returns move one-for-one with ex-ante interest rates. The theoretical foundation of the excess return hypothesis is described in Zhou (1996).

Since the change in expected inflation has an effect on nominal asset returns, it might be argued that the co-movement of nominal stock returns and nominal interest rates could be due to changes in expected 
inflation. For this reason, after incorporating real variables, the model in equation 7 (Appendix 1) is employed to test the excess return hypothesis.

Ordinary least squares are used to examine the one-for-one relationship between stock returns and interest rates. We first examine if the data are trend stationary to the order $I(0)$ or I(1) using the Phillips and Perron (1998) test and find they are trend stationary to the order I(1). Consequently, we use first differencing to de-trend the data. Finally, to allow for probable autocorrelation in the return data, the standard errors are adjusted using Newey and West's (1987) approach with a maximum lag of 4. This lag value for regressions with Newey-West standard errors represents the optimal lag provided by the Phillips and Perron (1998) unit root test.

Since equations 6 and 7 in Appendix 1 assume that the relationship between stock returns and matching maturity bond yields is ex-ante, the regression of real stock returns on ex-post real interest rates could involve endogeneity, resulting in biased coefficient estimates. To address this problem, an instrumental variable (IV) approach is used to estimate unbiased coefficients. Consistent with most empirical work in this area and with Zhou (1996), the past real short-term interest rate, $z_{t}=y_{t-3, t}$, is used as an instrumental variable. A good instrumental variable must be highly correlated with the independent variable. The correlation between the chosen instrumental variable and independent variable is shown in Table 4. Finally, the two-stage least squares (2SLS) model is used for the regressions.

Finally, a test for any structural change was conducted to confirm if a smaller sample size for Canadian term structure data has any impact on the results. To this end, a monthly dummy variable was created, taking a value of 0 for months prior to 1986:01 and a value of 1 for months following 1985:12. Then an interaction variable was created using a monthly dummy and 3-month interest rates. 3-month stock returns were then regressed against 3-month interest rates, the monthly dummy variable and an interaction variable. An F-Test was conducted 
to determine if the coefficients on the monthly dummy and interaction variable are both equal to zero.

\section{RESULTS}

\section{Canadian Stock Returns vs Canadian Term Structure}

\section{Stock Returns vs Interest Rates - Nominal}

Consistent with existing empirical work, equation 6 (Appendix 1) is first used to explore the relationship between nominal 3 to 84 month stock returns and matching maturity zero coupon bond yields as a proxy for nominal interest rates. Table 5 provides the regression results for short to long term horizon nominal stock returns on the matching maturity interest rates for the period 1986:01 to 2008:06. The standard errors reported in brackets are adjusted for serial autocorrelation and hetroscedasticity using the Newey-West approach.

The coefficients for bond yield are consistently negative, tend to decline with increasing $\mathrm{n}$, and are significant at the ten percent level for the three, thirty-six, and eighty-four month time horizons. The null hypothesis that the coefficient for interest rates is not significantly different from zero is thus rejected for some time horizons, but not for others. The results provide some evidence of a relationship between nominal Canadian stock returns and nominal Canadian interest rates for short, medium and long time horizons. However, they differ from the results reported by Zhou (1996) inasmuch as the indicated relationship is consistently negative in the Canadian case.

\section{Stock Returns vs Interest Rates - Real}

Equation 7 (Appendix 1) is used to investigate the relationship between real stock returns and matching maturity real interest rates for each of the six time horizons. The real data for stock return and interest rates are computed by deflating nominal data using periodic inflation. 
Table 6 shows the regression results using data for the period 1986:01 to 2008:06. The Newey-West approach is used to estimate the standard errors, adjusted for autocorrelation and hetroscedasticity.

The results using real data are similar to those obtained using nominal data inasmuch as the estimated coefficient for the interest rate is positive for the shortest time horizons - 12 months - but negative for all others. These results are, again, different than those of Zhou (1996), who reports a positive relationship using real data. However, only for the 84-month time horizon is the interest rate coefficient statistically significant and then only at the $10 \%$ level. Similarly, the $\mathrm{R}^{2}$ values do not indicate significant predictive power of Canadian real interest rates for Canadian real stock returns.

\section{Canadian Stock Returns vs US Term Structure}

\section{Canadian Stock Returns vs US Interest Rates - Nominal}

Equation 6 (Appendix 1) is applied using Canadian nominal stock returns and matching maturity US nominal interest rates for the period 1986:01 to 2008:06. The regression results are presented in Table 7; the standard errors are adjusted for serial autocorrelation and hetroscedasticity using the Newey-West approach.

The coefficient estimates are both positive and negative across the various horizons considered, with no particular pattern indicated. These results suggest that the US term structure has little predictive ability for Canadian stock returns. None of the interest rate coefficients are statistically significant and, once again, the $\mathrm{R}^{2}$ values are low indicating little predictive ability.

\section{Canadian Stock Returns vs US Interest Rates - Real}

The relationship between Canadian real stock returns and matching maturity US real interest rates is examined using equation 7 (Appendix 1) and data for the period 1986:01 to 2008:06. The nominal data for stock 
returns and bond yields are adjusted for inflation. Table 8 presents the regression results, with standard errors computed using the NeweyWest approach.

With real US term structure data the estimated coefficients for real interest rates are, once again, both positive and negative with no particular pattern across time horizons. The coefficients are statistically insignificant, except for the 3-month horizon, which is positive and is significant at the $1 \%$ level. This suggests support for the excess return hypothesis, but only for the short horizon.

\section{Stock Returns vs Term Structure using Instrumental Variable (IV)}

The two-stage least squares (2SLS) model with an instrumental variable, as discussed in Section 2.2, is used to avoid potential endogeneity and to estimate consistent and unbiased coefficients. Canadian real stock returns are regressed first using Canadian real interest rates and, then, using US real interest rates, with the past short-term interest rate as the instrumental variable.

\section{Canadian Stock Returns vs Canadian Interest Rates with Instrument}

Canadian real stock returns and matching maturity Canadian real interest rates for the period 1986:01 to 2008:06 are regressed using the 2SLS approach with the results summarized in Table 9. In this case, there is no need to first difference the data.

The coefficient estimates for the interest rates are negative except for the 36 month time horizon, where it is positive but close to zero. However, only the coefficient for the 12 and 84-months time horizons are statistically significant, albeit in both cases at the $1 \%$ level. These results suggest that Canadian real interest rates may affect Canadian real stock returns, but unlike Zhou's (1996) results for the US, the relationship is negative. 


\section{Canadian Stock Returns vs US Interest Rates with Instrument}

The relationship between Canadian real stock returns and matching maturity US real interest rates is examined through the 2SLS regression model as well. Table 10 provides the regression results with standard errors. Once again there is no need to first difference the data.

The coefficient on the interest rate for the short horizon of 3 months is negative but not significant. Most interestingly, we see strong support for the excess return hypothesis for the 24, 36, and 60 month time horizons, as coefficient estimates are close to 1 and significant at the $1 \%$ level. Unlike the relationship observed between real Canadian stock returns and real US interest rates using OLS regressions in section 3.2.2, the results here suggest that real Canadian stock returns move one-for-one with real US interest rates for medium to long time horizons.

\section{Test for Sample Size-Related Effects:}

As discussed earlier, Canadian term structure data are only available from 1986:01, except for the 3 month time horizon. The paper attempts to check for any structural change on account of this limitation. The comparative descriptive statistics for 3-month asset returns using large and small samples are reported in Table 3 in section 2.1. The regression results using large samples for the period 1956:04 to 2008:06 for 3-month Canadian stock returns with matching maturity interest rates are shown in Table 11. These results are similar to the results obtained earlier, when a smaller sample of 270 observations was used. The only notable change is in the coefficient on interest rates for the regression between Canadian real stock returns and US real interest rates, which is no longer statistically significant.

The question of interest is whether the availability of Canadian term structure data prior to 1986:01 would yield different results. If so, the conclusions indicated earlier in this paper would only apply to the period examined. 
The approach described in section 2.2 is used to test for possible structural change through comparing the results obtained for the large 3-month asset return sample with those obtained for the small 3-month sample. The monthly dummy variable is interacted with 3-month interest rates to create an interaction variable. Canadian stock returns for a 3month period are regressed against the 3-month interest rate, monthly dummy and interaction variable using the Newey-West approach with a maximum lag of 4 . The regression is followed by a post estimation test for the null hypothesis that coefficients on the monthly dummy and interaction variable are jointly equal to zero. Rejection of this null hypothesis would provide support for the argument that there exists no structural change due to an increase in the period examined. The regression results are summarized in Table 12.

The regressions and post estimation tests for the null hypothesis described in the preceding paragraph were conducted using both nominal and real Canadian stock returns with nominal and real Canadian and US interest rates. The null hypothesis is not rejected for any of the four regressions, suggesting that the results do not depend on the sample size.

\section{Conclusions}

Canadian nominal interest rates represented by zero coupon yields on Canadian treasury bonds appear to have some predictive ability for Canadian nominal stock returns. Likewise, in contrast to results obtained by Zhou (1996) for the US, the relationship is negative. Canadian real interest rates are inversely related, except for the 3-month horizon, to bond yields, though only significantly for the 84 month time horizon. These findings generally hold using a 2SLS regression for Canadian real stock returns on Canadian real interest rates, where statistically significant (and negative) relationships are observed for both 12-month and 84-month time horizons. 
On the other hand, the US term structure appears to have little relationship to Canadian stock returns. Regression results for Canadian stock returns and US nominal interest rate indicate coefficient signs that are both positive and negative, with no particular pattern across time horizons. Moreover, in all cases they lack statistical significance. The regression results for Canadian real stock returns and US real interest rates also have mixed signs, with the only significant relationship occurring in the short (3-month) horizon data. The two-stage least square regression results however indicate a one-for-one positive co-movement of Canadian real stock returns and US real interest rates, and for 24, 36, and 60 month time horizons. This relationship is quite unlike the one found between Canadian real stock returns and Canadian real interest rates, where the coefficients are negative in all cases except the 36month time horizon. Finally, the test using the 3-month extended sample size suggests that there have not been any structural changes over the period studied.

\section{REFERENCES}

Breen, William, Lawrence R. Glosten, and Ravi Jagannathan, 1989, Economic Significance of Predictable Variations in Stock Index Returns, fournal of Finance 44, 1177-1189. http://dx.doi.org/10.1111 /j.1540-6261.1989.tb02649.x

Campbell, John H., and John Ammer, 1993, What Moves the Stock and Bond Markets? A Variance Decomposition for Long-Term Asset Returns, Fournal of Finance 48, 3-37. http://dx.doi.org/10.1111/j.154 0-6261.1993.tb04700.x

Campbell, John Y., 1987, Stock returns and the term structure, fournal of Financial Economics 18, 373-399. http://dx.doi.org/10.1016/0304-4 05X(87)90045-6

Cleary, Sean, and Michael Inglis, 1998, Momentum in Canadian Stock Returns, Canadian Journal of Administrative Sciences 15, 279-291. http://dx.doi.org/10.1111/j.1936-4490.1998.tb00168.x 
Czaja, Marc-Gregor, and Hendrik Scholz, 2009, Interest Rate Risk Rewards in Stock Returns of Financial Corporations: Evidence from Germany, European Financial Management, 16(1), 124-154. http://dx.doi.org/10 $.1111 / \mathrm{j} .1468-036 \mathrm{X} .2008 .00455 . \mathrm{x}$

Deaves, Richard, and Peter Miu, 2007, Refining Momentum Strategies by Conditioning on Prior Long-term Returns: Canadian Evidence, Canadian fournal of Administrative Sciences 24, 135-145. http://dx. doi.org/10.1002/cjas.11

Domian, Dale L., and William Reichenstein, 2009, Long-Horizon Stock Predictability: Evidence and Application, fournal of Investing 18(3), 12-20. http://dx.doi.org/10.3905/JOI.2009.18.3.012

Ferson, Wayne E., 1989, Changes in Expected Security Returns, Risk, and the Level of Interest Rates, fournal of Finance 44, 1191-1217. http:// dx.doi.org/10.1111/j.1540-6261.1989.tb02650.x

Flannery, Mark J., and Christopher M. James, 1984, The Effect of Interest Rate Changes on the Common Stock Returns of Financial Institutions, fournal of Finance 39, 1141-1153. http://dx.doi.org/10.1111/j.1540-62 61.1984.tb03898.x

Jegadeesh, Narasimhan, 1990, Evidence of Predictable Behavior of Security Returns, Fournal of Finance 45, 881-898. http://dx.doi.org/10.1111/j. 1540-6261.1990.tb05110.x

Khoury, Nabil T., and Guy Melard, 1985, The Relationship between the Canadian Treasury-Bill Rate and Expected Inflation in Canada and in the United States, Canadian fournal of Administrative Sciences 2, 63-76.

McCulloch, John. H., and Heon-Chul Kwon, 1993, U.S. Term Structure Data, 1947-1991, Ohio State University Working Paper 93-6.

Newey, Whitney K., and Kenneth D. West, 1987, A Simple, Positive Semi-Definite, Heteroskedasticity and Autocorrelation Consistent Covariance Matrix, Econometrica 55, 703-708. http://dx.doi.org/10.2 307/1913610

Phillips, P. C. B., and P. Perron, 1988, Testing for a unit root in time series regression. Biometrika 75, 335-346. 
146 The BRC Academy Journal of Business Vol. 6, No. 1

Shiller, Robert J., 1981, Do Stock Prices Move Too Much to be Justified by Subsequent Changes in Dividends? American Economic Review 71, 421-436.

Tilak, John, 2015, Canadian Stocks-TSX falls as US rate hike fears hit gold shares, Reuters, Feb 6, http://www.reuters.com/article/2015/02/ 06/markets-canada-stocks-idUSL1N0VG28A20150206

Zhou, Chunsheng, 1996, Stock Market Fluctuations and the Term Structure, US Federal Reserve Board 3, mimeo.

\section{Citation Information}

Chamberlain, Trevor W., and Abdul-Rahman Khokhar. "Testing the Excess Return Hypothesis: The Canadian Case." The BRC Academy fournal of Business 6, no. 1 (2016): 131-146. http://dx.doi.org/10.15239/ j.brcacadjb.2016.06.01.ja06

\section{Web Appendix}

A web appendix for this paper is available at:

http://dx.doi.org/10.15239/j.brcacadjb.2016.06.01.wa06 